\title{
Pre-germinative treatments applied to Chionanthus pubescens and $C$. virginicus seeds for sexual propagation ${ }^{1}$
}

\author{
Mario José Añazco Romero², \\ Brayan Steven Haro Mediavilla² ${ }^{2}$ María Isabel Vizcaíno Pantoja ${ }^{3}$
}

\section{ABSTRACT}

Chionanthus pubescens Kunth and C. virginicus seeds present double dormancy, what represents a problem for their sexual reproduction, given that it prevents them from reaching adequate germination rates. This research aimed to apply pregerminative treatments to overcome the double dormancy in C. pubescens and C. virginicus seeds, as well as to improve both the germination speed and the amount of obtained seedlings. A completely randomized design was applied, with four treatments for each species (soaking seeds in cold water, soaking seeds in hot water, mechanical scarification and control) and three replications. For C. pubescens, the pregerminative treatment with the best results was mechanical scarification, with a $39.22 \%$ germinative capacity; while, for $C$. virginicus, the best treatment was soaking seeds in hot water $(49.00 \%)$.

KEYWORDS: Oleaceae, seed dormancy, germination.

\section{INTRODUCTION}

The Oleaceae family, in Ecuador, is represented by one genus (Chionanthus) and three species (C. colonchensis, $C$. implicatus L. and C. pubescens Kunth) (Palacios 2011).

The geographical distribution of the three species occurs in four natural regions. In the coastal area, C. colonchensis is endemic to western Ecuador, where it is found in the tropical or basal belt between 500 and $600 \mathrm{~m}$ above the sea level. C. implicatus is found in the Amazon (Fernández-Alonso \& CogolloPacheco 2017). C. pubescens, native of the Andean region (Peralta 2017), is also reported in Galapagos, in the city of Puerto Baquerizo Moreno (provincial

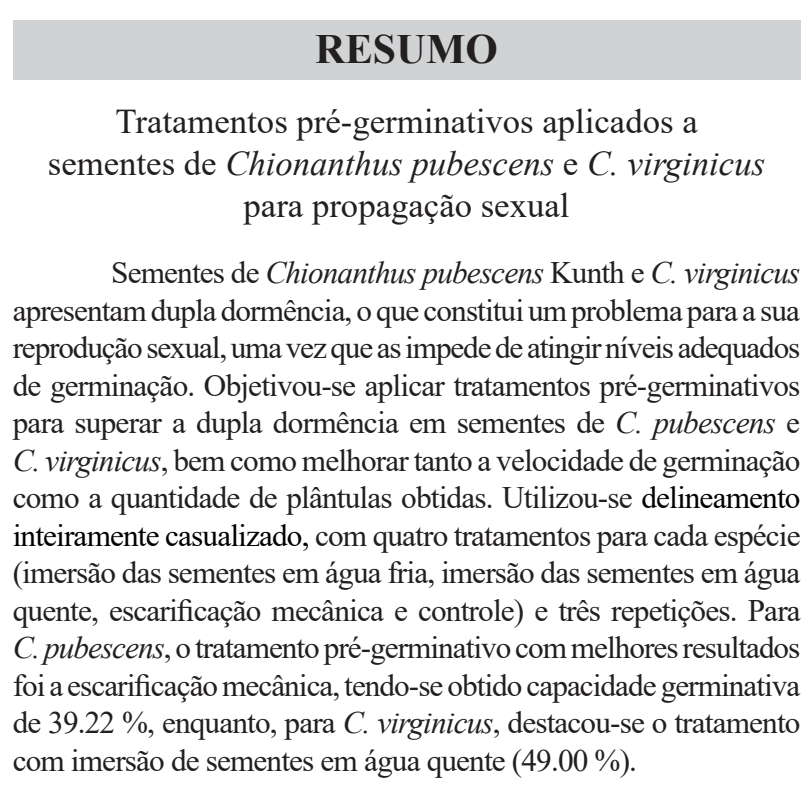

PALAVRAS-CHAVE: Oleaceae, dormência de sementes, germinação.

capital), at $15 \mathrm{~m}$ above the sea level (San Cristobal Island).

Also found in Ecuador, C. virginicus is a species introduced from the United States of America (Chan \& Marquard 1999), which has adapted to the physiographical and ecological conditions of the Andean region of this country (Ruales 2007).

The two species present in the Andean region, C. pubescens [synonymous of Linociera pubescens (Kunth) Eichler] and C. virginicus, are known by the vernacular name "arupo" (arupu in Quichua).

C. pubescens is recognized by the tonalities of its flowers, which range from pale pink to intense pink, depending on the degree of senescence of the flowers or on the different varieties within the species

\footnotetext{
${ }^{1}$ Received: Dec. 02, 2020. Accepted: Mar. 09, 2021. Published: Apr. 05, 2021. DOI: 10.1590/1983-40632021v5166875.

${ }^{2}$ Universidad Técnica del Norte, Carrera de Ingeniería Forestal, Ibarra, Ecuador. E-mail/ORCID: marioanazco@gmail.com/0000-0003-4393-6485; bsharom@utn.edu.ec/0000-0001-7367-6659.

${ }^{3}$ Sakura Asesores, Ibarra, Ecuador. E-mail/ORCID: ma.isabel.vizcaino@gmail.com/0000-0001-8418-764X.
} 
(Peralta 2017). The other species, C. virginicus, has white flowers.

C. pubescens is originally from southern Ecuador and northern Peru. In the latter, it is known by the name "chuquil" or tree of love (Peralta 2017). C. virginicus is known as the Virginia arupo or fringe tree, native to the United States of America, where it can be found from southern Pennsylvania and New Jersey to southern Florida and west of Texas (Chan \& Marquard 1999).

The primary physiographical and microclimatic characteristics where the species are found in the Andean region of Ecuador are altitudes of 1,800-3,050 $\mathrm{m}$ above the sea level, average annual temperature of $11-21^{\circ} \mathrm{C}$, average annual precipitation of $300-1,500 \mathrm{~mm}$ and relative humidity of $79 \%$ (Peralta 2017).

The wood of $C$. pubescens is hard and used to make the end pieces of tools and rollers for homemade mills (Lojan 2003). The bark, in powder form, is used as a purgative in Azuay and Cañar (De la Torre et al.2008). The seeds are a raw material used to create environment-friendly fashion accessories (Vargas 2010).

The bark of $C$. virginicus roots contains antioxidants and shows a potential value in the production of natural food and cosmetic products (Gülcin et al. 2008).

Despite all the aforementioned uses, in the Andean region of Ecuador, the primary use of these two species is ornamental, due to their attractive flowers. Proportionally, the use of pink-flowered species is greater than that of white flowers.

The two species present similarities and differences, in terms of architecture and organography. The architecture of the two species is similar, corresponding to a mixed-core model, formed by the trunk and branches, known as Troll's model. They are also similar in size, being medium-sized trees that can reach up to $20 \mathrm{~m}$ in height and $50 \mathrm{~cm}$ in basal diameter (Bernal et al. 2015, Koeser et al. 2015).

They present taproot with a lot of branching (Peralta 2017); opposite-intersected branches; the bark has a grey color with lenticels on the stems and branches (Palacios 2011); simple, opposite-crossed, whole leaves with pinnate venation, a glabrous adaxial surface and a pubescent abaxial surface. The leaves are light green when young and acquire a dark green tone as they advance in age (Peralta 2017).

The flowers are conspicuous, arranged in compound inflorescences called panicles. The panicle consists of six to nine racemes, with 40-283 flowers grouped in these racemes (Peralta 2017).

It is a monoecious, hermaphroditic species that blossoms annually (between April and October, depending on the physiographic, edaphic and microclimatic characteristics of each site). In Quito, flowers appear from April to September. In Loja, flowering begins in August and lasts until October (Peralta 2017).

Trees do not blossom all at once, and flowering does not begin in a specific part of the tree. Once flowering has occurred, the defoliation or falling of all the leaves occurs at the same time. The flowering process lasts about 40 days, after which a total renewal of the leaves takes place (Peralta 2017). They are slow-growing trees, with the first flowering occurring around eight to ten years (Lojan 2003, Peralta 2017).

In addition to the difference due to the tone of the pink and white flowers, other differences are present in anthers, fruits and seeds. C. pubescens has two anthers, whereas a high percentage of flowers with two anthers is observed in C. virginicus, which, sometimes, has flowers with three anthers and rarely with four (Palacios 2011, Koeser et al. 2015).

The fruit is an elliptical drupe, with a fleshy mesocarp and a lignified endocarp, indehiscent, with a single seed. $C$. pubescens fruits are light green when tender, combined with purple spots later, and vinous (red) to black at maturity, with a pointed apex. The ripe fruit can show an average of $2.0 \mathrm{~cm}$ in length and $1.2 \mathrm{~cm}$ in width; it is less pointed, with a smooth consistency and a combined sweet and bitter taste. Birds, such as the blackbird (Turdus fuscater) consume these fruits and contribute to seed dissemination. The pits (seeds) are light brown with intense striations, with $1.7 \mathrm{~cm}$ long and $0.8 \mathrm{~cm}$ wide, on average (Peralta 2017).

C. virginicus fruits are light green when tender, turning from brown to black when ripe. The ripe fruit can be $1.8 \mathrm{~cm}$ long and $1.2 \mathrm{~cm}$ wide, on average, less pointed, soft in consistency and bitter in taste. Neither birds nor animals have been observed consuming these fruits. The seeds are darker brown in color, with less-marked streaks, $1.6 \mathrm{~cm}$ long and $0.9 \mathrm{~cm}$ wide, on average, as compared to those of the other species (Koeser et al. 2015).

The seeds of species within the Chionanthus genus have in common their state of dormancy. A study carried out in Asia with Chionanthus retusus indicates that conventional propagation by seeds 
requires one to two years to break dormancy (Tar et al. 2018).

Both the C. pubescens and C. virginicus species have the same dormancy problem. The type of dormancy is combined exogenous/endogenous, also called double dormancy, because it affects the seminal cover and the embryo at the same time (Redcay \& Frett 1990, Peralta 2017). Specifically, the first type of dormancy evidenced is exogenous-mechanical, that is, mechanical resistance of the pericarp, or covering, to the embryo growth. The second type of dormancy is endogenous-physiological, that is, an inhibitory physiological mechanism that prevents germination (Willan 1991).

The $C$. pubescens dormancy is due to an extrinsic factor. The covering that protects the seed also stunts the early absorption of water and oxygen, what makes germination possible (Peralta 2017). The fruits (seeds) consumed by frugivorous birds, such as blackbirds, germinate more quickly than the seeds that fall to the ground or are collected from trees. This is because the seed coating is softened or brushed into its gizzard, as it passes through the bird's digestive tract (Peralta 2017).

C. virginicus is traditionally propagated from seeds by cold scarification. It takes two years to break the double dormancy, caused by a hard endocarp and endosperm inhibitors (Dirr 1994).

The techniques used to dormancy breaking include physical and mechanical pre-germinative treatments. Thus, this research aimed to apply pregerminative treatments to overcome the double dormancy of $C$. pubescens and C. virginicus seeds, as well as to improve their germination speed and percentage of obtained seedlings.

\section{MATERIAL AND METHODS}

The $C$. virginicus seeds were collected in $\mathrm{La}$ Tola (0'13'28.6'S and 78²2'13.0'W), in Tumbaco, Pichincha province, Ecuador, while the C. pubescens seeds were collected in the Pichincha province $\left(0^{\circ} 13\right.$ '28.6"S and $\left.78^{\circ} 22^{\prime} 13.0^{\prime \prime} \mathrm{W}\right)$, and in Otavalo $\left(0^{\circ} 13^{\prime} 09.3^{\prime \prime} \mathrm{N}\right.$ and $\left.78^{\circ} 16^{\prime} 30.3^{\prime \prime} \mathrm{W}\right)$ and Cotacachi $\left(0^{\circ} 18^{\prime} 00.2^{\prime \prime} \mathrm{N}\right.$ and $\left.78^{\circ} 15^{\prime} 52.4^{\prime \prime} \mathrm{W}\right)$, in the Imbabura province. The seeds of both species were collected between August 04 and 09, 2018, and the seed analysis was carried out between August 10 and 20, 2018.

The seedbed was located at the Yuyococha Farm nursery, owned by the Universidad Técnica del Norte, Ibarra, Ecuador. The nursery is located at an altitude of 2,228 $\mathrm{m}$ above the sea level, with an average annual temperature of $18.4{ }^{\circ} \mathrm{C}$ and average rainfall of $589.3 \mathrm{~mm}_{\text {year }}^{-1}$.

The seeds were stored between August 21 and 31,2018 , and the germination phase was evaluated until January 10, 2019.

The criteria used to define the trees to collect the seeds from were: i) fully ripe fruits; ii) seeds without the presence of physical damage; iii) trees with the presence of pink flowers and others with white flowers; iv) collection of seeds from 16 trees of each species (approximately 15 years old).

The seed analysis protocols followed the International Seed Testing Association standards (ISTA 2016). Tests were carried out to evaluate the number of seeds $\mathrm{kg}^{-1}$, purity percentage and moisture content.

The pre-germinative treatments were: i) soaking seeds in cold water - the purpose was to remove the inhibitors by soaking the seeds in cold tap water, replacing the water every 24 hours. The soaking time was 72 hours; ii) soaking seeds in hot water - the seeds were placed in a container, in a proportion of 4 to 5 times their volume of hot water, at a temperature of $50{ }^{\circ} \mathrm{C}$. The heat source was immediately removed, and the seeds were allowed to soak for $80 \mathrm{~min}$, during which the temperature was decreasing; iii) mechanical scarification - it consisted of applying the scarification method with manual sanding (80). Additionally, a control was included, where no type of pre-germinative treatment was applied.

The statistical design was a two-factor arrangement, the first factor being the $C$. pubescens (pink) and C. virginicus (white) species, whereas the second factor corresponded to the pre-germinative treatments, including the control.

A completely randomized design was used, with four treatments for each species and three replications per treatment, totaling 24 experimental units. A total of 300 seeds was used for each experimental unit, with 3,600 seeds per species and 7,200 seeds used throughout the experiment.

Two methods were applied for the germination data analysis: descriptive (graphs of daily and cumulative germination in time intervals) and analytical [germination (\%), average germination time and germination speed index].

The number of germinated seeds was counted daily for 77 days. Afterwards, the germination 
rate was calculated according to Balocchi et al. 1998; the average germination time according to Bewley \& Black (1994); and the germination speed index according to Maguire (1962).

To analyze the collected data, the analysis of variance (Anova) and Tukey test at $1 \%$ of probability were performed for the variables of the treatments.

\section{RESULTS AND DISCUSSION}

The seed analysis of the C. pubescens and C. virginicus species presented similar results, regarding purity and weight. The purity was $55.93 \%$ for $C$. pubescens and $54.84 \%$ for $C$. virginicus, whereas $4,545.45$ seeds $\mathrm{kg}^{-1}$ were found for C. pubescens and $4,411.76$ seeds $\mathrm{kg}^{-1}$ for $C$. virginicus.

Lojan (2003) reported that the number of seeds $\mathrm{kg}^{-1}$ of C. pubescens is about 2,500. Moreover, Peralta (2017) stated that, in $1 \mathrm{~kg}$ of $C$. pubescens seeds collected in the Tumbaco Valley, in Quito, he found between 3,448 and 3,470 seeds $\mathrm{kg}^{-1}$, what differs from the $4,545.45$ seeds kg-1 obtained in the present study.

Regarding moisture, the results differed, with a higher percentage of moisture for $C$. pubescens $(21.21 \%)$ than for $C$. virginicus $(8.82 \%)$.

In general, the $C$. virginicus seeds presented the best germination results in all treatments, including the control, when compared to C. pubescens (Figure 1).

For $C$. pubescens, the pre-germinative treatment with the best results was mechanical scarification, leading to $39.22 \%$ of germination. For C. virginicus, the best treatment was soaking in hot water, leading to $49.00 \%$ of germination (Figure 1).

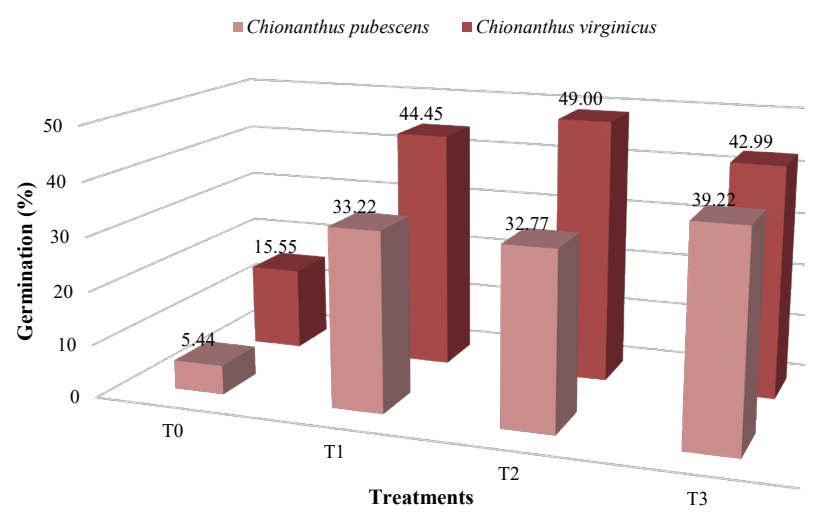

Figure 1. Germination percentage of Chionanthus pubescens and $C$. virginicus. T0: control treatment; T1: soaking in cold water; T2: soaking in hot water; T3: mechanical scarification.
Vasquez \& Yunga (2008), using seed scarification of $C$. pubescens in sand for 10 days, achieved $36 \%$ of germination, and, in water, they obtained $26 \%$, which is lower than the results achieved in the present investigation, showing that the type of pre-germinative treatment is influential in achieving higher germination percentages.

According to the germination speed index, the mechanical scarification treatment for $C$. pubescens presented the highest value (1.52 seeds day $\left.{ }^{-1}\right)$; while, for $C$. virginicus, the soaking in hot water treatment registered the highest result (1.90 seeds day $\left.{ }^{-1}\right)$. The implementation of an adequate pre-germinative treatment applied to each species results in obtaining a larger amount of seedlings in a shorter period of time.

The germination of $C$. pubescens seeds subjected to the mechanical scarification treatment began at 57 days after sowing, 58 days for soaking in cold water, 62 days for soaking in hot water, and 60 days for the control. For the $C$. virginicus seeds, germination began at 52 days for the control, 56 days for mechanical scarification, 62 days for soaking in hot water, and 65 days for soaking in cold water (Figure 2). Quishpe (2009) observed 32 days after sowing for the first seedlings of $C$. pubescens. A treatment in which the seed was immersed in water at $50{ }^{\circ} \mathrm{C}$, for $80 \mathrm{~min}$, was applied. Both species presented different results, in response to the applied treatments. In this case, the earlier the germination begins, the lesser is the time to obtain the seedlings.

For $C$. pubescens, the highest number of germinated seeds was observed at 86 days after sowing, in the mechanical scarification treatment; while, for C. virginicus, it was recorded at 107 days, in the soaking in cold water treatment (Figure 3). Moreover, Quishpe (2009) points out that, in a study with $C$. pubescens seeds, the highest germination energy was presented at 135 days after sowing.

Chan \& Marquard (1999), in a study with C. virginicus seeds, extracted the embryo from the endosperm and the testa, and germination occurred from seven to ten days. Ten months later, the embryos had developed into seedlings comparable in size with two-year-old seedlings obtained by natural germination. These results confirm the need to subject the seeds to pre-germinative treatments to accelerate the germination process and obtain seedlings in a shorter period of time.

The daily germination turned out to be irregular during the experiment, since, after 113 days, 

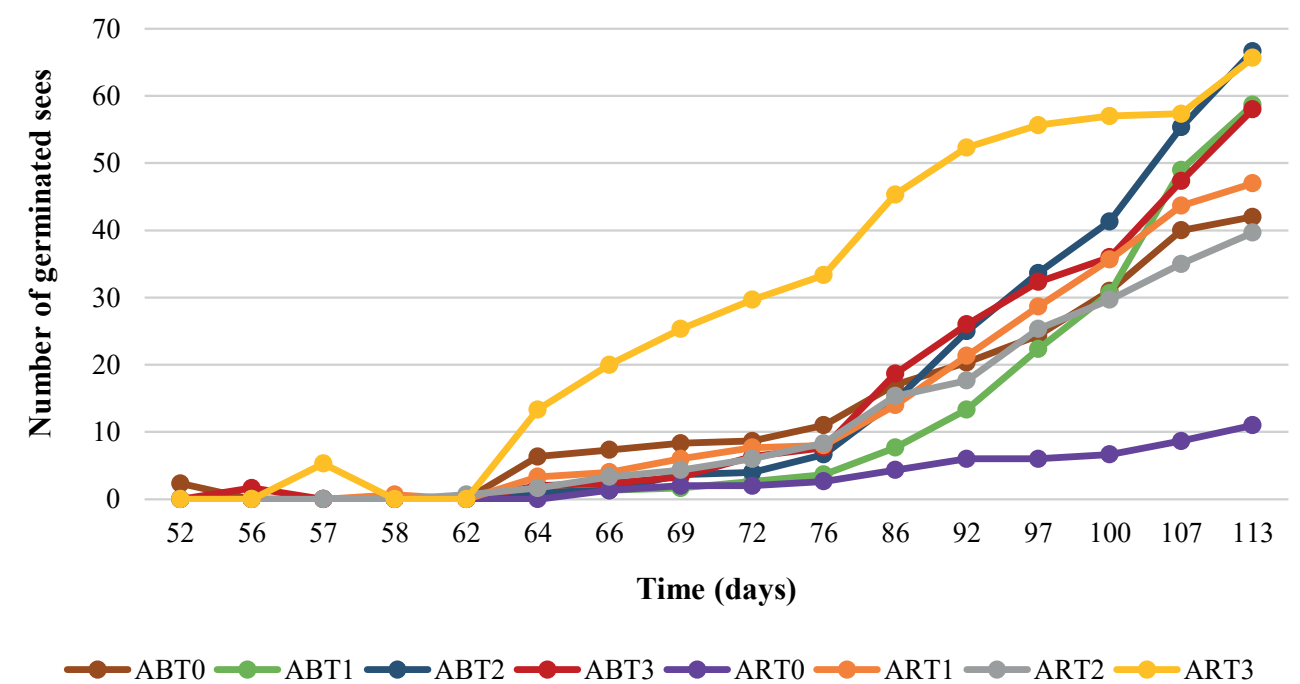

Figure 2. Accumulated germination of Chionanthus pubescens and C. virginicus seeds, during the evaluation period. AB: C. pubescens; AR: C. virginicus; T0: control treatment; T1: soaking in cold water; T2: soaking in hot water; T3: mechanical scarification.

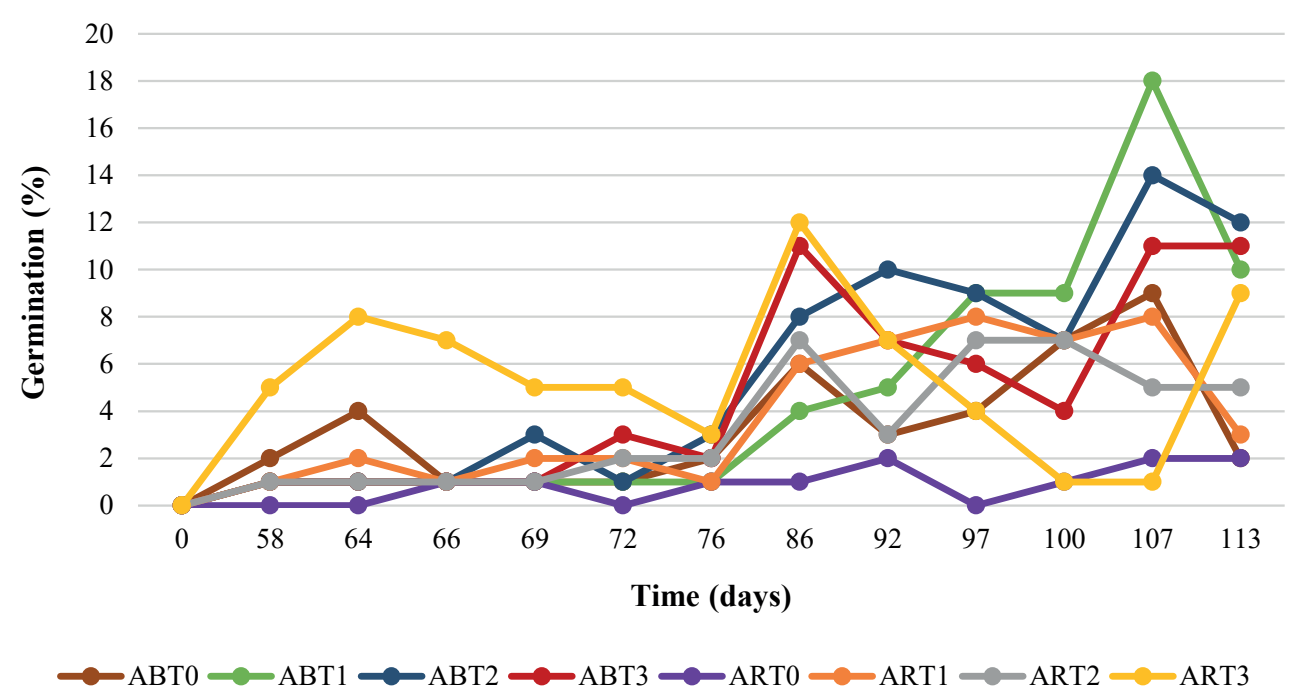

Figure 3. Daily germination record for Chionanthus pubescens and C. virginicus seeds, during the evaluation period. AB: C. pubescens; AR: $C$. virginicus; T0: control treatment; T1: soaking in cold water; T2: soaking in hot water; T3: mechanical scarification.

the seeds continued germinating. In this research, the immediate sowing of the seeds after harvesting and their corresponding drying were applied. The non-germinated seeds did not present problems; nevertheless, as an optimal rest time was not provided to them, the germination time lengthened.

Quisphe (2009) recommends letting the seeds rest for three to four months after harvesting, because the germination process is more homogeneous after this time. The freshly harvested seeds that are almost immediately sown after a three-week drying period in the shade generally present an uneven germination and, given that, from start to finish, germination may last around 8 months.

In the Anova, for germination at 77 days after the experiment was established, it was determined that, for the treatments in general, such as for the factorial arrangement and its interaction, the $\mathrm{F}$ (Fisher test) values were highly significant at $1 \%$ of probability (Table 1), and, consequently, this means that the treatments are statistically very different.

The results for the Tukey test, concerning the species, showed that two different ranges were formed. C. virginicus surp C. pubescens, with an 
Table 1. Statistical analysis for the seed germination of Chionanthus pubescens and C. virginicus.

\begin{tabular}{|c|c|c|c|c|c|c|}
\hline \multicolumn{7}{|c|}{ Statistical analysis } \\
\hline Variable & $\mathrm{N}$ & $\mathrm{R}^{2}$ & \multicolumn{2}{|c|}{$\mathrm{R}^{2} \mathrm{Aj}$} & \multicolumn{2}{|l|}{$\mathrm{CV}$} \\
\hline Germination (10 Jan. 2019) & 24 & 0.99 & \multicolumn{2}{|c|}{0.98} & \multicolumn{2}{|l|}{5.7} \\
\hline & $-\mathrm{A}$ & of var & & & & \\
\hline Source of variation & SS & DF & MS & $\mathrm{F}$ & p-value & ST \\
\hline Treatments & $44,459.33$ & 7 & $6,351.33$ & 204.88 & $<0.0001$ & $* *$ \\
\hline Species & $5,890.67$ & 1 & $5,890.67$ & 190.02 & $<0.0001$ & $* *$ \\
\hline Pre-germinative treatments $(\mathrm{PG})$ & $37,300.33$ & 3 & $12,433.44$ & 401.08 & $<0.0001$ & $* *$ \\
\hline Species * PG & $1,268.33$ & 3 & 422.78 & 13.64 & 0.0001 & $* *$ \\
\hline Error & 496 & 16 & 31 & & & \\
\hline Total & $44,955.33$ & 23 & & & & \\
\hline
\end{tabular}

average of 113.33 germinated seeds at 77 days. Furthermore, the results concerning the treatments for both species, again, showed that two ranges were formed. The pre-germinative treatments showed better results when compared to the control treatment, which presented the worst average: 29.5 germinated seeds at 77 days after sowing. Therefore, it is evident that pre-germinative treatments are necessary to achieve a high germination rate.

Concerning total interaction, when the soaking in hot water treatment was applied to $C$. virginicus, the highest average was shown in the "A" range, with 147 germinated seeds. For C. pubescens, the best treatment was mechanical scarification, with 117.67 germinated seeds. These treatments presented the best performance of the experiment, while the controls presented the worst performance.

\section{CONCLUSIONS}

For Chionanthus pubescens, the pregerminative treatment with the best results was mechanical scarification, with $39.22 \%$ of germinative capacity; while, for $C$. virginicus, the best treatment was soaking seeds in hot water (49.00\%).

\section{REFERENCES}

BALOCCHI, L. O.; LÓPEZ, C. I.; LUKASCHEWSKY, P. J. Características físicas y germinativas de las semillas de especies pratenses nativas y naturalizadas del dominio húmedo de Chile. Agro Sur, v. 26, n. 1, p. 1-13, 1998.

BERNAL, R.; GRADSTEIN, S. R.; CELIS, M. Catálogo de plantas y líquenes de Colombia. Bogotá: Universidad Nacional de Colombia, 2015.
BEWLEY, J. D.; BLACK, M. Seeds. In: BEWLEY, J. D.; BLACK, M. Seeds. Boston: Springer, 1994. p. 1-33.

CHAN, R. C.; MARQUARD, R. D. Accelerated propagation of Chionanthus virginicus via embryo culture. Hortscience, v. 34, n. 1, p. 140-141, 1999.

DE LA TORRE, L.; NAVARRETE, P.; MURIEL, P.; MACÍA, M.; BALSLEV, H. (ed.). Enciclopedia de las plantas útiles del Ecuador. Quito: Herbario QCA de la Escuela de Ciencias Biológicas de la Pontificia Universidad Católica del Ecuador, 2008.

DIRR, M. A. The fringe tree, spectacular for its variability in growth habit, leaf color and size. Nursery Manager, v. 6, n. 1, p. 24-26, 1994.

FERNÁNDEZ-ALONSO, J. L.; COGOLLO-PACHECO, A. Sinopsis de Chionanthus (Oleaceae) en Colombia y países limítrofes y descripción de una nueva especie. Anales del Jardín Botánico de Madrid, v. 74, n. 1, p. 1-12, 2017.

GÜLÇIN, I.; ELIAS, R.; GEPDIREMEN, A.; TAOUBI, K.; KÖKSAL, E. Antioxidant secoiridoids from fringe tree (Chionanthus virginicus L.). Wood, Science and Technology, v. 43, n. 3, p. 195-212, 2008.

INTERNATIONAL SEED TESTING ASSOCIATION (ISTA). Reglas internacionales para el análisis de las semillas. Bassesdorf: ISTA, 2016.

KOESER, A. K.; HASING, G.; FRIEDMAN, M. H.; IRVING, R. B. Trees: north \& central Florida. Gainesville: Institute of Food and Agricultural Sciences, 2015.

LOJAN, L. El verdor de los Andes ecuatorianos: realidades y promesas. Quito: Proyecto Desarrollo Forestal Participativo en los Andes, 2003.

MAGUIRE, J. D. Speed of germination: aid in selection and evaluation for seedling emergence and vigor. Crop Science, v. 2, n. 2, p. 176-177, 1962. 
PALACIOS, W. Árboles del Ecuador. Quito: Ministerio del Ambiente del Ecuador, 2011.

PERALTA, E. El arupo (Chionanthus pubescens Kunt), árbol ornamental con potencial de uso en Ecuador. Quito: Instituto Nacional de Investigación Agropecuaria, 2017.

QUISHPE, J. Evaluación de seis tratamientos pre germinativos y cuatro tipos de sustratos para la propagación de arupo (Chionanthus pubescens Kunt). 2009. Tesis (Doctorado en Ingeniería Forestal) - Escuela Superior Técnica del Chimborazo, Riobamba, 2009.

REDCAY, S.; FRETT, J. J. Germination of doubly dormant Chionanthus virginicus seeds. Hortscience, v. 25, n. 6 , p. 622-627, 1990.

RUALES, C. Estudios para la recuperación de la flora nativa en el Valle de Tumbaco - distrito metropolitano de Quito: inventario florístico y ensayo de propagación vegetativa. 2007. Tesis (Doctorado en Gestión Ambiental) Universidad San Francisco de Quito, Quito, 2007.

TAR, K.; NAING, A.; AI, T.; CHUNG, M.; KIM, C. Optimization of factors influencing in vitro immature seed germination in Chionanthus retusus. Journal of Plant Biotechnology, v. 45, n. 4, p. 347-356, 2018.

VARGAS, C. Uso de materiales biodegradables para accesorios de moda. 2010. Tesis (Doctorado en Diseño Industrial) - Pontificia Universidad Católica del Ecuador, Ambato, 2010.

VÁSQUEZ, P.; YUNGA, J. Efecto de cuatro (4) porcentajes de zeolita como sustrato y dos (2) métodos pregerminativos en 10 (diez) especies forestales. 2008. Tesis (Doctorado en Ingeniería Agrícola) - Universidad del Azuay, Cuenca, 2008.

WILLAN, R. L. Guía para la manipulación de semillas forestales. Roma: FAO, 1991. 